\title{
Oral and maxillofacial biopsied lesions in Brazilian pediatric patients: A 16-year retrospective study
}

\section{Biópsias de lesões orais e maxilo-faciais em pacientes pediátricos brasileiros: estudo retrospectivo de 16 anos}

\begin{abstract}
Purpose: To survey oral and maxillofacial lesions biopsied in a Brazilian pediatric hospital. Methods: Biopsy records over a 16-year period (1992-2008) were retrieved from the files of the Anatomy and Pathology Service, Hospital Presidente Dutra, Federal University of Maranhão, Brazil. Pediatric cases patients aged 16 years old or younger were selected. Oral and maxillofacial diagnoses were grouped into 10 categories, and lesions were evaluated for age, gender, anatomic location and pathological diagnosis. Data were analyzed using descriptive statistics.

Results: Of a total of 3,550 pediatric biopsies, 88 cases $(2.48 \%)$ were located in oral or maxillofacial sites. Similar incidence rates were observed between the genders and the prevalence of lesions was highest in the permanent dentition period (>12-16 years old). Maxilla was the most commonly affected anatomic location. As regards the diagnostic categories, the highest number of lesions was in the hyperplastic/reactive category. The most frequently encountered lesions were inflammatory fibrous hyperplasia and mucocele. Malignant lesions were rarely described.

Conclusion: This study shows a similar trend to that reported in previous studies on the most frequent oral and maxillofacial lesions found in the pediatric population. The majority of lesions detected were benign, and malignant lesions were diagnosed in a very low number of patients.
\end{abstract}

Key words: Pathology; epidemiology; children

\section{Resumo}

Objetivo: Realizar levantamento das lesões orais e maxilo-faciais biopsiadas em um hospital pediátrico brasileiro.

Metodologia: Biópsias registradas ao longo de um período de 16 anos (1992-2008) foram recuperadas dos arquivos do Serviço de Anatomia e Patologia do Hospital Presidente Dutra, Universidade Federal do Maranhão, Brasil. Pacientes com até 16 anos de idade foram selecionados. Os diagnósticos de lesões orais e maxilo-faciais foram agrupados em 10 categorias e as lesões foram avaliadas quanto a idade, sexo, localização anatômica e diagnóstico. Os dados foram analisados usando estatística descritiva.

Resultados: De um total de 3.550 biópsias registradas, 88 casos $(2,48 \%)$ estavam localizadas na região oral ou maxilo-facial. Taxas de incidência similares foram observadas entre os sexos e a prevalência de lesões foi maior na dentição permanente (> 12-16 anos). A maxila foi a localização anatômica mais acometida. Quanto às categorias de diagnóstico, o maior número de lesões foi encontrado na hiperplásica/reativo. As lesões mais freqüentemente encontradas foram a hiperplasia fibrosa inflamatória e mucocele. Lesões malignas foram raramente descritas.

Conclusão: Este estudo mostra uma tendência semelhante à relatada em estudos anteriores sobre as lesões mais freqüentes na região oral e maxilo-facial na população pediátrica. A maioria das lesões detectadas foram benignas, enquanto as malignas foram diagnosticadas em um número muito reduzido de pacientes.

Palavras-chave: Patologia; epidemiologia; criança

\author{
Monique Maria Melo Mouchrek a \\ Letícia Machado Gonçalves ' \\ José Ribamar Sabino Bezerra-Júnior c \\ Enara de Cássia Silva Maia a \\ Rubenice Amaral da Silva d \\ Maria Carmen F. Nogueira da Cruz d
}

- School of Dentistry, Federal University of Maranhão, São Luís, MA, Brazil

b Department of Prosthodontics and Periodontology, Piracicaba Dental School, State University of Campinas, Piracicaba, SP, Brazil

c Department of Oral Diagnosis, Semiology Area, Piracicaba Dental School, State University of Campinas, Piracicaba, SP, Brazil

d Department of Dentistry II, School of Dentistry, Federal University of Maranhão, São Luís, MA, Brazil

\author{
Correspondence: \\ Letícia Machado Gonçalves \\ Department of Dentistry II \\ Universidade Federal do Maranhão \\ Avenida Bacanga, S/N \\ São Luís, MA - Brazil \\ 65010-600 \\ E-mail: lets.mg@gmail.com
}

Received: May 10, 2011

Accepted: September 21, 2011

Conflict of Interest Statement: The authors state that there are no financial and personal conflicts of interest that could have inappropriately influenced their work.

Copyright: (C) 2011 Mouchrek et al.; licensee EDIPUCRS. This is an Open Access article distributed under the terms of the Creative Commons AttributionNoncommercial-No Derivative Works 3.0 Unported License. 


\section{Introduction}

There are several differences between the adult and child populations. Children differ from the general population not only because of their small size, but also because certain lesions have a predilection for this population group such as Langerhans cell histiocytosis and some types of lymphoma, leukemia, and hemangioma (1). In addition, compared with their adult counterparts, some childhood oral and maxillofacial lesions differ considerably in their histopathology, clinical behavior, and management (2).

Despite a considerable volume of literature written about pediatric oral and maxillofacial lesions in different countries $(1,2-7)$, this has not yet been thoroughly documented or analyzed in Brazilian children (4,8). Since geographic distribution is a source of variation, the occurrence of this type of lesions in different geographic areas may be a relevant topic to investigate.

The objectives of this study were to conduct a survey of oral and maxillofacial biopsied lesions in a Brazilian pediatric hospital and to compare the epidemiological data with those of previous studies.

\section{Methods}

Biopsy records over 16-year period (1992-2008) were retrieved from the files of the Anatomy and Pathology Service, Hospital Presidente Dutra, Federal University of Maranhão, UFMA. Pediatric cases of patients aged 16 years old or younger were selected. For the oral and maxillofacial lesions, data collected included age, gender, anatomic location and pathological diagnosis. The subjects were divided into three age groups according to their dentition period: primary dentition period ( $0-6$ years old), mixed dentition period ( $>6-12$ years old) and, permanent dentition period $(>12-16$ years old).

Biopsies were ranked in 10 categories (9), as follow: hyperplasic/reactionary lesions, benign neoplasm of soft tissue, oral mucosa lesions, cystic lesions, periapical inflammations, bone pathologies, salivary gland lesions, malignant neoplasm, and healthy tissues and teeth. Inconclusive histopathological diagnoses or those in which biopsies were not performed in oral or maxillofacial sites were excluded from this study. Data were analyzed by descriptive statistics using the SPSS statistical package (SPSS Inc., Chicago, IL, USA).

\section{Results}

Out of a total of 3,550 pediatric biopsies received at the Anatomy and Pathology Service in the above-mentioned period, 88 cases $(2.48 \%)$ were located in the oral or maxillofacial regions. Similar prevalence was observed between girls (54.5\%) and boys (45.5\%). The prevalence of these lesions was highest in the permanent dentition period (> 12-16 years old) (38\%), followed by the mixed dentition
(> 6-12 years old) (34\%) and primary dentition periods (0-6 years) $(28 \%)$. The maxilla $(22 \%)$ was the most commonly affected anatomic site, followed by the skin (21\%), mandibular region (14\%) and lower lips (13\%) (Fig. 1). The most common conditions diagnosed individually were inflammatory fibrous hyperplasia $(10.1 \%)$, mucocele $(10.1 \%)$, odontoma $(8.9 \%)$, and dentigerous cyst $(7.6 \%)$ (Fig. 2).

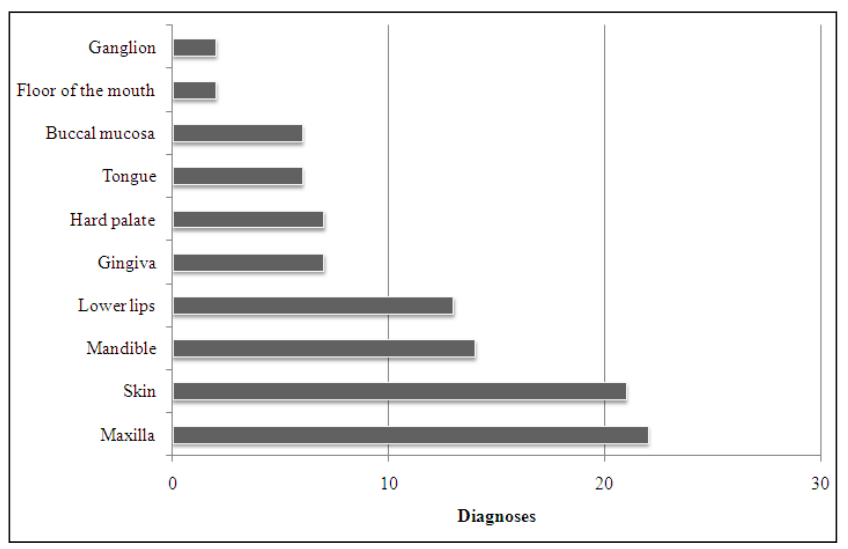

Fig. 1. The anatomical distribution of oral and maxillofacial lesions.

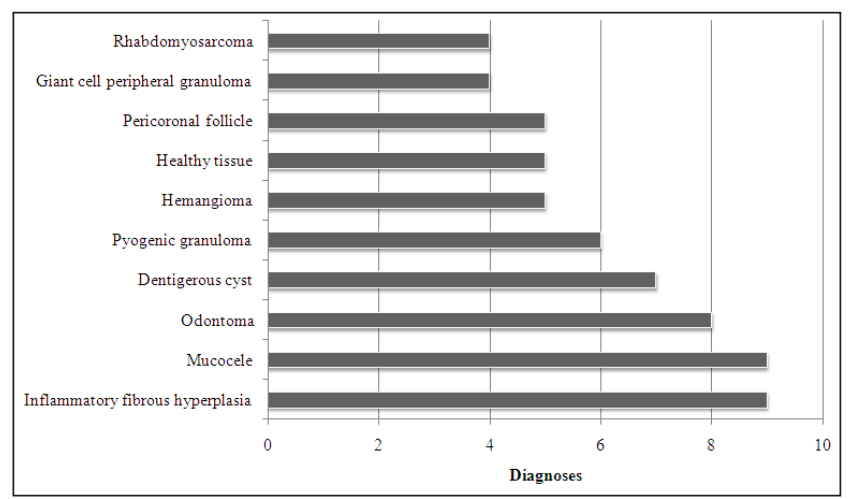

Fig. 2. Most frequent diagnoses retrieved from the Anatomy and Pathology Service files.

With regard to the diagnostic categories, the largest number of cases occurred in the hyperplasic/reactive category $(27.3 \%)$, salivary gland lesions $(13.6 \%)$, and benign soft tissue neoplasms (12.7\%), in this order (Table 1). Inflammatory fibrous hyperplasia was also the most common condition in the hyperplastic/reactive category $(37.5 \%)$, followed by pyogenic granuloma $(25 \%)$, and giant cell peripheral granuloma (16.6\%). Mucocele was the most frequent condition in the salivary gland lesion group $(75 \%)$. 
Table 1. Distribution of the most common diagnoses in each category.

\begin{tabular}{|c|c|c|}
\hline Categories & $\begin{array}{l}\text { Total number } \\
\text { of biopsies }\end{array}$ & Percentage \\
\hline Hyperplasic/reactionary lesions & 24 & 27.3 \\
\hline Inflammatory fibrous hyperplasia & 9 & 10.1 \\
\hline Pyogenic granuloma & 6 & 6.7 \\
\hline Giant cell peripheral granuloma & 4 & 4.5 \\
\hline Peripheral ossifying fibroma & 3 & 3.4 \\
\hline Gingival hyperplasia & 1 & 1.3 \\
\hline Parulis & 1 & 1.3 \\
\hline Benign neoplasm of soft tissue & 11 & 12.7 \\
\hline Hemangioma & 5 & 5.7 \\
\hline Squamous papilloma & 2 & 2.2 \\
\hline Fibroma & 2 & 2.2 \\
\hline Nevus & 1 & 1.3 \\
\hline Giant cell fibroma & 1 & 1.3 \\
\hline Oral mucosa lesions & 0 & 0 \\
\hline Cystic lesions & 10 & 11.5 \\
\hline Dentigerous cyst & 7 & 7.6 \\
\hline Periapical cyst & 1 & 1.3 \\
\hline Eruption cyst & 1 & 1.3 \\
\hline Unclassified cysts of odontogenic origin & 1 & 1.3 \\
\hline Periapical inflammations & 3 & 3.4 \\
\hline Periapical granuloma & 3 & 3.4 \\
\hline Odontogenic tumors & 10 & 11.5 \\
\hline Odontoma & 8 & 8.9 \\
\hline Keratocystic odontogenic tumor & 1 & 1.3 \\
\hline Ameloblastoma & 1 & 1.3 \\
\hline Bone pathologies & 0 & 0 \\
\hline Salivary gland lesions & 12 & 13.6 \\
\hline Mucocele & 9 & 10.1 \\
\hline Ranula & 2 & 2.2 \\
\hline Pleomorphic adenoma & 1 & 1.3 \\
\hline Malignant neoplasms & 8 & 8.9 \\
\hline Rhabdomyosarcoma & 4 & 4.5 \\
\hline Langerhans cell histiocytosis & 2 & 2.2 \\
\hline Burkitt's lymphoma & 1 & 1.3 \\
\hline Nevoid basal cell carcinoma & 1 & 1.3 \\
\hline Healthy tissues and teeth & 10 & 11.5 \\
\hline Healthy tissue & 5 & 5.75 \\
\hline Pericoronal follicle & 5 & 5.75 \\
\hline Total & 88 & 100 \\
\hline
\end{tabular}

Hemangioma was the most prevalent lesion in the benign neoplasm group ( $45.5 \%)$, followed by squamous papilloma (18.2\%), and fibroma (18.2\%). Odontoma accounted for $80 \%$ of the odontogenic tumors. Malignant lesions were rarely diagnosed, corresponding to $8.9 \%$ of the total sample size.

\section{Discussion}

There were 3,550 cases of pediatric biopsies in this study of which $2.48 \%$ were in the oral or maxillofacial region. This figure was similar to numbers mentioned in the majority of previous studies. It has been reported that oral and maxillofacial lesions in pediatric patients account for less than $10 \%$ of all biopsies $(3-4,5,8,10-14)$. However, other authors have found percentages of oral and maxillofacial biopsies ranging between 11 and $27.2 \%$ of the total number of pediatric cases $(1,6,15-17)$. The disparity between different studies may be due to the inclusion criteria. For instance, some studies only recruited children up to 15 years of age $(8,10,11,13)$, whereas others accepted older children in their studies $(5,15,17)$. In addition, factors such as the time interval during which the study was conducted, geographical region, genetic background of the population, and type of institution where the study was conducted contribute to the differences (1).

It is difficult to determine in which age interval pediatric oral and maxillofacial lesions occurs most frequently, because of the different age stratifications used in different studies. The present study showed that most pediatric lesions occurred in the permanent dentition period, which is similar to the time interval reported in the studies of AlKhateeb et al. (2), Jones and Franklin (5), Das and Das (15), Rioboo-Crespo et al. (18), Laikui et al. (19) and, Shulman et al. (20). Whereas, other authors demonstrated that most pediatric oral and maxillofacial lesions were found in the mixed dentition period $(3,8,10)$. With regard to prevalence in the genders, there was a similar distribution of cases between girls and boys, which is in agreement with the data published elsewhere $(1,3,5,10,14,21)$. When considering the anatomical location, the maxilla was the most common site, as supported by Maia et al. (4) and Lima et al. (14).

The material evaluated in this study comprised a wide spectrum of lesions, ranging from inflammatory processes to malignant tumors. The hyperplastic/reactionary category comprised $27.3 \%$ of all pediatric lesions and inflammatory fibrous hyperplasia was the most common lesion in this category. Previous studies reported this category to be in the range from $15.7 \%$ to $66.1 \%(8,10,11,12,15,17)$. Moreover, inflammatory fibrous hyperplasia and giant cell peripheral granuloma were ranked as the lesions most frequently found $(4,10)$.

Salivary gland lesions were the second most frequent group. In this category, mucocele represented $10.1 \%$ of all biopsies, revealing a considerable occurrence in pediatric populations. Mucocele also appeared as one of the main conditions diagnosed in these populations in previous reviews $(4,5,8,11,15,17)$.

As regards benign soft tissue neoplasms, hemangioma was the most prevalent condition diagnosed, followed by squamous papilloma, fibroma, nevus and giant cell fibroma. Similar results have been reported $(2,3,10)$ although Lima et al.(14) found that fibroma was the condition most frequently found. It is important to emphasize the fact that hemangioma 
may not always be biopsied. Therefore, the occurrence of hemangioma might be even higher than the number of cases reported by these authors. On the other hand, there was a very low number of malignant biopsies in the present study, accounting for only 8 cases ( $8.9 \%$ of the biopsies). Similar results have been reported by Jones and Franklin (5), who detected malignancy in 1\% of all the biopsies analyzed.

In the present study, the cystic category comprised $11.5 \%$ of all pediatric lesions. Previous studies have reported that lesions in this group ranged from $10.7 \%$ to $17.6 \%$ $(1,10,11,15,17)$ and that the dentigerous cyst was the most frequently encountered lesion in this category, followed by the periapical cyst. This was similar to the findings of the present study.

Odontoma accounted for $8.9 \%$ of the odontogenic tumors, a similar percentage being mentioned in other reports $(3,5,8,10,11,15,17)$. Whereas, Dhanuthai et al. (1) found that ameloblastoma was the most frequent diagnosis when considering odontogenic tumors. This may be explained by the fact that most odontomas are asymptomatic lesions and in several countries radiographic examination is not routinely performed, and patients would seek medical attention only when the lesions produced symptoms or disfigurement. Ideally, every child should undergo routine oral examination as a necessary part of diagnosis. Without it, certain pathological conditions may be missed (1).

An essential aspect to be addressed when analyzing the results of the present study is that there are variations in the prevalence of typical lesions in any given population group (14). Moreover, it is worth mentioning that the data retrieved in the present study do not reproduce the prevalence of oral and maxillofacial lesions diagnosed by pediatric dentists in clinical practice, since some pathologies, such as herpes, aphthous ulcerations and even hemangioma, are diagnosed on the basis of clinical features, while the present study was based exclusively on biopsied lesions.

\section{Conclusions}

This is a large-scale study of pediatric oral and maxillofacial lesions conducted in Brazil. The results show a similar trend to that reported in previous studies. The majority of the lesions detected were benign, and malignant lesions were diagnosed in a very small number of the patients. The epidemiological survey of oral and maxillofacial lesions biopsied in children is important to determine the prevalence of lesions in different geographic areas. This type of study also contributes to the characterization of lesion specificities in the pediatric population, providing general dentists and pediatric dentists with a solid background for the diagnosis and treatment of these entities.

\section{Acknowledgments}

This study was partly supported by CNPq, São Luís, MA, Brazil. All authors have declared no conflict of interest.
References
1. Dhanuthai K, Banrai M, Limpanaputtajak S. A retrospective study of paediatric oral lesions from Thailand. Int J Paediatr Dent 2007; 17:248-53.

2. Al-Khateeb T, Al-Hadi Hamasha A, Almasri NM. Oral and maxillofacial tumours in north Jordanian children and adolescents: a retrospective analysis over 10 years. Int J Oral Maxillofac Surg 2003;32:78-83.

3. Sato M, Tanaka N, Sato T, Amagasa T. Oral and maxillofacial tumours in children: a review. Br J Oral Maxillofac Surg 1997;35:92-5.

4. Maia DM, Merly F, Castro WH, Gomez RS. A survey of oral biopsies in Brazilian pediatric patients. ASDC J Dent Child 2000;67:128-31.

5. Jones $A V$, Franklin CD. An analysis of oral and maxillofacial pathology found in children over a 30-year period. Int J Paediatr Dent 2006;16:19-30.

6. Bessa CFN, Santos PJB, Aguiar MCF, do Carmo MAV. Prevalence of oral mucosal alterations in children from 0 to 12 years old. J Oral Pathol Med 2004;33:17-22.

7. Crivelli MR, Aguas S, Adler I, Quarracino C, Bazerque P. Influence of socioeconomic status on oral mucosa lesion prevalence in schoolchildren. Community Dent Oral Epidemiol 1988; 16:58-60.

8. Sousa FB, Etges A, Corrêa L, Mesquita RA, de Araújo NS. Pediatric oral lesions: a 15-year review from São Paulo, Brazil. J Clin Pediatr Dent 2002;26:413-8.

9. Happonen RP, Ylipaavalniemi P, Calonius B. A survey of 15,758 oral biopsies in Finland. Proc Finn Dent Soc 1982;78:201-6.

10. Gültelkin SE, Tokman B, Türkseven MR. A review of paediatric oral biopsies in Turkey. Int Dent J 2003;53:26-32.

11. Chen YK, Lin LM, Huang HC, Lin CC, Yan YH. A retrospective study of oral and maxillofacial biopsy lesions in a pediatric population from southern Taiwan. Pediatr Dent 1998;20: 404-10.

12. Keszler A, Guglielmotti MB, Dominguez FV. Oral pathology in children. Frequency, distribution and clinical significance. Acta Odontol Latinoam 1990;5:39-48.

13. Ulmansky M, Lustmann J, Balkin N. Tumors and tumor-like lesions of the oral cavity and related structures in Israeli children. Int J Oral Maxillofac Surg 1999;28:291-4. 
14. Lima GDS, Fontes ST, de Araújo LMA, Etges A, Tarquinio SBC, Gomes APN. A survey of oral and maxillofacial biopsies in children: a single-center retrospective study of 20 years in Pelotas-Brazil. J Appl Oral Sci 2008;16:397-402.

15. Das S, Das AK. A review of pediatric oral biopsies from a surgical pathology service in a dental school. Pediatr Dent 1993;15:208-211.

16. Maaita JK. Oral tumors in children: a review. J Clin Pediatr Dent 2000;24:133-5.

17. Skinner RL, Davenport WD, Weir JC, Carr RF. A survey of biopsied oral lesions in pediatric dental patients. Pediatr Dent 1986;8:163-7.

18. Rioboo-Crespo MDR, Planells-del Pozo P, Rioboo-García R. Epidemiology of the most common oral mucosal diseases in children. Med Oral Patol Oral Cir Bucal 2005; 10: 376-87.

19. Laikui L, Hongwei L, Hongbing J, Zhixiu H. Epithelial salivary gland tumors of children and adolescents in west China population: a clinicopathologic study of 79 cases. J Oral Pathol Med 2008;37:201-5.

20. Shulman JD. Prevalence of oral mucosal lesions in children and youths in the USA. Int J Paediatr Dent 2005;15:89-97.

21. Parlak AH, Koybasi S, Yavuz T, Yesildal N, Anul H, Aydogan I, et al. Prevalence of oral lesions in 13- to 16-year-old students in Duzce, Turkey. Oral Dis 2006;12:553-8. 